\title{
Effect of Ni on Microstructure and Mechanical Property of a Co- Ti-V-Based Superalloy
}

\author{
Pengjie Zhou $\mathbb{D}^{1},{ }^{1}$ Xinkang Gao, ${ }^{1}$ Dehang Song, ${ }^{1}$ Yinbing Liu, ${ }^{1}$ and Jun Cheng ${ }^{2,3}$ \\ ${ }^{1}$ School of Materials Science and Engineering, Jiangsu University of Science and Technology, Zhenjiang 212003, China \\ ${ }^{2}$ Northwest Institute for Non-Ferrous Metal Research, Shanxi Key Laboratory of Biomedical Metal Materials, Xi'an 710016, China \\ ${ }^{3}$ State Key Laboratory of Solidification Processing, Northwestern Polytechnical University, Xi'an 710072, China
}

Correspondence should be addressed to Pengjie Zhou; zhoupengjie@just.edu.cn

Received 5 October 2020; Revised 9 April 2021; Accepted 11 May 2021; Published 27 May 2021

Academic Editor: Renato Buzio

Copyright (c) 2021 Pengjie Zhou et al. This is an open access article distributed under the Creative Commons Attribution License, which permits unrestricted use, distribution, and reproduction in any medium, provided the original work is properly cited.

The effect of $\mathrm{Ni}$ on microstructure, elemental partition behavior, $\gamma^{\prime}$ phase solvus temperature, lattice misfit between $\gamma$ and $\gamma^{\prime}$ phases, and mechanical properties of the Co-8Ti-11V-xNi alloys was investigated. The result shows that the lattice misfit in the alloys decreases from $0.74 \%$ to $0.61 \%$ as the Ni content increases from 0 to $10 \%$, and the average sizes of the cuboidal $\gamma^{\prime}$ phase were measured to be $312.10 \mathrm{~nm}, 112.86 \mathrm{~nm}$, and $141.84 \mathrm{~nm}$ for the Co-8Ti-11V, Co-8Ti-11V-5Ni, and Co-8Ti-11V-10Ni, respectively. $\mathrm{Ti}, \mathrm{V}$, and $\mathrm{Ni}$ exhibit a slight tendency to partition into the $\gamma^{\prime}$ phase, while Co shows a slight tendency to partition into the $\gamma$ phase. The solvus temperatures of the $\gamma^{\prime}$ phase were measured to be $1167^{\circ} \mathrm{C}, 1114^{\circ} \mathrm{C}$, and $1108^{\circ} \mathrm{C}$ for the $\mathrm{Co}-8 \mathrm{Ti}-11 \mathrm{~V}$, Co-8 Ti-11V-5Ni, and Co-8Ti-11V-10Ni alloys, respectively, by using differential scanning calorimetry (DSC). Moreover, the yield strength and ultimate strength of the Co-8Ti-11V, Co-8Ti-11V-5Ni, and Co-8Ti-11V-10Ni alloys were investigated, and the yield strength and ultimate strength of the $10 \mathrm{Ni}$ alloy were highest, at $219 \mathrm{MPa}$ and $240 \mathrm{MPa}$. After compression at $1000^{\circ} \mathrm{C}$, the dislocations cannot effectively shear the $\gamma^{\prime}$ phase in the $0 \mathrm{Ni}$ and $10 \mathrm{Ni}$ alloys, resulting in a relatively high compressive strength of the $0 \mathrm{Ni}$ and $10 \mathrm{Ni}$ alloys. However, the $\gamma^{\prime}$ phase of the $5 \mathrm{Ni}$ alloy is no longer visible, and its strength is the lowest.

\section{Introduction}

The superalloys, which are normally used in the industrial environments with elevated temperature and high pressure, can be divided into three classes named as nickel-based, cobalt-based, and iron-based superalloys [1,2]. Among various types of superalloys, the nickel-based superalloys reinforced by the coherent ordered L12 structure phase are more widely utilized in modern industries than the other two types [3-5]. However, the carbide-strengthened Cobased superalloys exhibit higher incipient melting temperature and better corrosion resistance than the Ni-based superalloys. But it is believed that the lack of GCP phases in traditional carbide-strengthened Co-based superalloys leads to their inferior high-temperature strengths [6-13].

In 2006, Sato et al. reported $\gamma / \gamma^{\prime}$-strengthened Co-Al-Wbased superalloys, which possess some outstanding proper- ties [14]. The discovery of the Co-Al-W-based superalloy indicated a promising candidate for high-temperature applications. However, some researchers found the $\gamma^{\prime}$ phase in the Co-Al-W ternary alloy was metastable [15]. It needs to incorporate some alloying elements like $\mathrm{Ni}, \mathrm{Ti}, \mathrm{B}$, and $\mathrm{Cr}$ to improve thermal stability [16-18]. The $\gamma^{\prime}-\mathrm{Co} 3(\mathrm{Al}, \mathrm{W})$ in the ternary Co-Al-W system has a relatively low solvus temperature [19]. Other research tried to increase the volume fraction of the $\gamma^{\prime}$ phase by increasing the contents of $\mathrm{W}$ element, resulting in an increase in the mass density of the alloys [20-22]. Since then, most research studies have focused on replacing some of the $\mathrm{W}$ with various refractory elements, such as $\mathrm{Ta}$ and $\mathrm{Nb}[14,23]$, which can stabilize the $\gamma^{\prime}$ phase, increase the $\gamma^{\prime}$ phase solvus temperature, and improve the high temperature strength. Also, the Ni element was added to the Co-Al-W ternary system, which has been found to stabilize the $\gamma^{\prime}$ phase [24]. Following the discovery that the $\gamma / \gamma^{\prime}$ 
two-phase structure of the Co-Al-Mo-Nb alloy by Makineni et al. [25-28], some research studies have focused on $\mathrm{W}$ free Co-based superalloys with $\gamma / \gamma^{\prime}$ strengthening. The L12-ordered phases were discovered in other Co-based superalloys, such as $\mathrm{Co}-\mathrm{V}, \mathrm{Co}-\mathrm{Ti}$, and Co-Ta systems [2932]. However, among these Co-based systems, only the $\gamma^{\prime}$ phase in the Co-Ti system is considerably stable [33]. In the past, some ternary systems have been identified to exhibit ordered L12 structure $\gamma^{\prime}$ phase, such as the Co-Ti-Cr ternary system and Co-Ti-V ternary system $[34,35]$. The mass density of Co-Ti-Cr alloys hardened by the $\gamma^{\prime}$ phase is about $14 \%$ lower than that of a typical Co-Al-W alloy and has a small lattice misfit between $\gamma$ and $\gamma^{\prime}$ and a higher $\gamma^{\prime}$ phase volume fraction [34]. Recently, Ruan et al. reported the effects of $\mathrm{Al}$ and $\mathrm{Ni}$ on the microstructure, phase stability, and hightemperature mechanical properties of Co-Ti-V alloys [36].

In this study, three Co-Ti-V alloys with different $\mathrm{Ni}$ contents were prepared, and the effects of $\mathrm{Ni}$ in microstructure, elemental partition behavior, lattice misfits between $\gamma$ and $\gamma$ ' phases, and mechanical properties of the Co-Ti-V-based superalloys were investigated.

\section{Materials and Methods}

Experimental alloys with $80 \mathrm{~g}$ in weight were prepared from high-purity Co (99.9 wt \%), Ti (99.9 wt \%), V (99.95 wt \%), and $\mathrm{Ru}(99.9 \mathrm{wt} \%)$ in a vacuum arc furnace. The cast ingots were turned over and remelted 5 times to achieve the composition homogeneity. Then, the experimental alloys were put into quartz capsules and filled with argon gas. The nominal compositions of the three experimental alloys are listed in Table 1. In this study, there are three experimental alloys defined as $0 \mathrm{Ni}, 5 \mathrm{Ni}$, and $10 \mathrm{Ni}$, respectively.

The cast materials were solutionized at $1100^{\circ} \mathrm{C}$ for $48 \mathrm{~h}$ and aged at $870^{\circ} \mathrm{C}$ for $72 \mathrm{~h}$ under an argon atmosphere. To obtain the best mechanical properties and investigate the morphologies of the $\gamma^{\prime}$ phase, the samples were quickly quenched into ice water after the heat treatment. The microstructural morphology was investigated by using scanning electron microscopy (SEM) (Zeiss Merlin Compact), which was operated at $10 \mathrm{kV}$. The samples were mechanically polished and then electroetched in a solution of HNO3 (vol. $5 \%)+\mathrm{CH} 3 \mathrm{COOH}($ vol. 15\%)+distilled water (vol. $85 \%$ ) for a few seconds before observations. The Image-Pro Plus 6.0 software was used to calculate the average sizes of the $\gamma^{\prime}$ phase. The $\gamma / \gamma^{\prime}$ two-phase lattice misfits were investigated by X-ray diffraction (XRD-6000) analysis, using $\mathrm{CuK} \alpha$ radiation at $40 \mathrm{kV}$ and $40 \mathrm{~mA}$. The tested powders were machined from bulk materials. The curves were fitted by using the data analysis and technical graphing software Origin Pro 9.1. Details of the microstructure and partitioning behavior of each element were obtained by using a transmission electron microscope (JEM-2100F TEM) equipped with the Oxford-80T energy spectrometer (EDS). Thin foil specimens for TEM analyses were prepared by twin jet electropolishing in a solution of $\mathrm{HClO}_{4}$ (vol. 5\%) $+\mathrm{CH}_{3} \mathrm{CH}_{2} \mathrm{OH}$ (vol. 95\%), and the voltage was $19 \mathrm{~V}$ and the temperature was $-30^{\circ} \mathrm{C}$, respectively.
TABLE 1: The nominal composition of the experimental alloy (at. \%).

\begin{tabular}{llllc}
\hline Alloy & Co & $\mathrm{Ti}$ & $\mathrm{V}$ & $\mathrm{Ni}$ \\
\hline Co-8Ti-11V & Bal. & 8 & 11 & 0 \\
Co-8Ti-11V-5Ni & Bal. & 8 & 11 & 5 \\
Co-8Ti-11V-10Ni & Bal. & 8 & 11 & 10 \\
\hline
\end{tabular}

Besides, the high-temperature compression tests were performed through a Gleeble-3800 thermal simulator, which is equipped with the strain rate of $3 \times 10^{-4} \mathrm{~s}^{-1}$ and a heating rate of $10^{\circ} \mathrm{C} / \mathrm{s}$ at $1000^{\circ} \mathrm{C}$. The compression samples were made the shape with a $\Phi 6 \mathrm{~mm} \times 9 \mathrm{~mm}$ rod by wire cutting. The solvus temperature of the $\gamma^{\prime}$ phase was examined though differential scanning calorimetry (DSC) with an argon atmosphere at a heating rate of $20^{\circ} \mathrm{C} / \mathrm{min}$.

\section{Results and Discussions}

3.1. Morphologies of the $\gamma^{\prime}$ Phase. Figure 1 shows scanning electron microscopy (SEM) micrographs for ternary Co-8Ti$11 \mathrm{~V}$, quaternary Co-8Ti-11V-5Ni, and quaternary Co-8Ti$11 \mathrm{~V}-10 \mathrm{Ni}$, which indicates the presence of cuboidal $\gamma^{\prime}-\mathrm{L} 12$ precipitates after being electroetched. The SEM micrograph of the $0 \mathrm{Ni}$ alloy is shown in Figure 1(a), which possesses large size and high volume fraction of the $\gamma^{\prime}$ phase. Figure 1(b) is a SEM micrograph of the $5 \mathrm{Ni}$ alloy, showing a uniform cuboidal shape of the $\gamma^{\prime}$ phase, and the size of the $\gamma^{\prime}$ precipitates was distributed in a large scatter. It is obvious that the coarsening behavior of the $\gamma^{\prime}$ phase was restrained by the adding of $5 \% \mathrm{Ni}$, and the $5 \% \mathrm{Ni}$ alloy possesses smaller size and low volume fraction of the $\gamma^{\prime}$ phase. A more uniform cuboidal shape of the $\gamma^{\prime}$ phase is shown in Figure 1(c). The average sizes of the $\gamma^{\prime}$ phase were measured to be $312.10 \mathrm{~nm}, 112.86 \mathrm{~nm}$, and $141.84 \mathrm{~nm}$ for the $0 \mathrm{Ni}, 5 \mathrm{Ni}$, and $10 \mathrm{Ni}$ alloys, respectively, by using the Image-Pro Plus 6.0 software. The results indicate that adding Ni content can retard the coarsening behavior of the $\gamma^{\prime}$ phase. Meher et al. [37] measured the coarsening behavior of Co-10Al-10W at $800^{\circ} \mathrm{C}$. Pandey et al. [38] and Wang et al. [39] also reported that the coarsening behavior of the $\gamma^{\prime}$ phases was limited by adding Re.

3.2. The Lattice Misfit between $\gamma$ and $\gamma^{\prime}$ Phases. The lattice misfit between $\gamma$ and $\gamma^{\prime}$ phases was calculated by X-ray diffraction analysis with different components of alloys. The data were measured in the range of $2 \theta$ from $49^{\circ}$ to $52.5^{\circ}$, and a scanning speed of $0.125^{\circ} / \mathrm{min}$ was selected for XRD testing. Figure 2 shows the X-ray diffraction (200) peaks of the $0 \mathrm{Ni}, 5 \mathrm{Ni}$, and $10 \mathrm{Ni}$ alloys. The lattice constant of $\gamma$ and $\gamma^{\prime}$ and lattice misfit between $\gamma$ and $\gamma^{\prime}$ in the alloys $0 \mathrm{Ni}$, $5 \mathrm{Ni}$, and $10 \mathrm{Ni}$ were measured, which are shown in Table 2.

As can be seen from Figure 2, compared with the $0 \mathrm{Ni}$ alloy, the diffraction peak of the $\gamma^{\prime}$ phase of the $5 \mathrm{Ni}$ alloy was slightly right shifted, indicating that the lattice constant of the $\gamma^{\prime}$ phase in the $5 \mathrm{Ni}$ alloy dropped, which decreases the lattice constant gap between the $\gamma$ and $\gamma^{\prime}$ phases of the $5 \mathrm{Ni}$ alloy. Compared with the other two alloys, the diffraction 


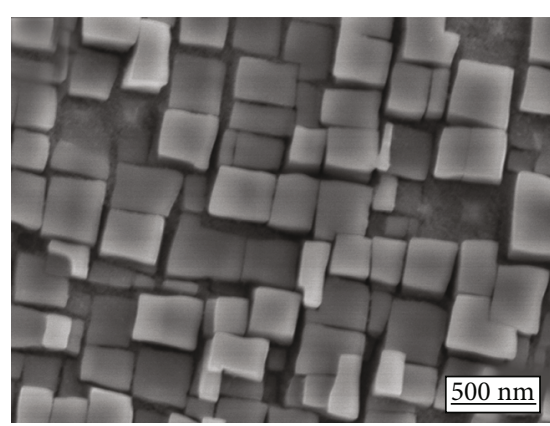

(a)

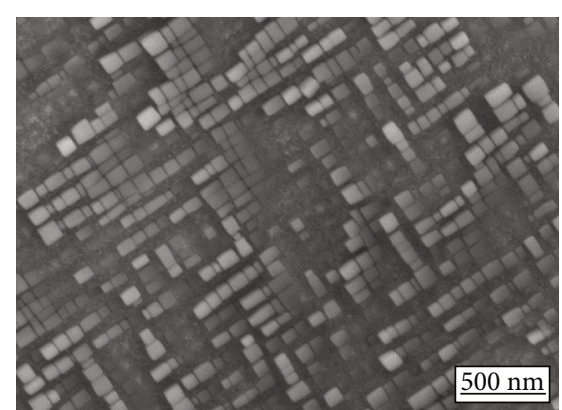

(b)

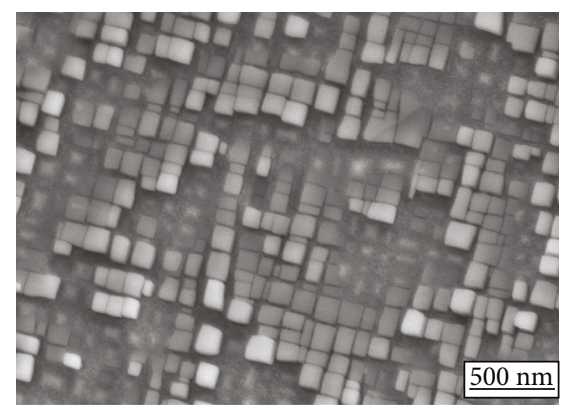

(c)

Figure 1: SEM micrograph of the (a) $0 \mathrm{Ni}$ alloy, (b) $5 \mathrm{Ni}$ alloy, and (c) $10 \mathrm{Ni}$ alloy, after solution treatment for $48 \mathrm{~h}$ at $1100^{\circ} \mathrm{C}$ followed by aging treatment for $72 \mathrm{~h}$ at $870^{\circ} \mathrm{C}$. The samples were electroetched.

peak of the $\gamma^{\prime}$ phase of the $10 \mathrm{Ni}$ alloy was further right, thus further decreasing the lattice constant of the $\gamma^{\prime}$ phase of the $10 \mathrm{Ni}$ alloy, and the lattice constant gap between $\gamma$ and $\gamma^{\prime}$ also decreased.

For the $0 \mathrm{Ni}$ alloy, the lattice constant of the $\gamma^{\prime}$ phase is $0.3611 \mathrm{~nm}$ and the lattice constant of the $\gamma$ phase is $0.3584 \mathrm{~nm}$, so the lattice misfit is $0.74 \%$. When the Ni content increases to $5 \%$, the lattice constants of $\gamma^{\prime}$ and $\gamma$ in the $5 \mathrm{Ni}$ alloy are $0.3607 \mathrm{~nm}$ and $0.3583 \mathrm{~nm}$, respectively. So the lattice misfit between $\gamma$ and $\gamma^{\prime}$ phases is $0.68 \%$. Compared to the $0 \mathrm{Ni}$ alloy, the lattice misfit in the $5 \mathrm{Ni}$ alloy decreases. The lattice constants between $\gamma^{\prime}$ and $\gamma$ phases of the $10 \mathrm{Ni}$ alloy are $0.3593 \mathrm{~nm}$ and $0.3571 \mathrm{~nm}$, respectively, and the lattice misfit between $\gamma$ and $\gamma^{\prime}$ phases is $0.61 \%$. Compared to the $0 \mathrm{Ni}$ and $5 \mathrm{Ni}$ alloys, the lattice misfit in the $10 \mathrm{Ni}$ alloy decreased. The result shows that the lattice misfit between $\gamma$ and $\gamma^{\prime}$ phases decreases with increasing Ni content.

The lattice parameter misfit of Co-Ti-1Re, Co-Ti-3Re, and $\mathrm{Co}-\mathrm{Ti}-5 \mathrm{Re}$ alloys when aged at $800^{\circ} \mathrm{C}$ for $24 \mathrm{~h}$ were $72 \%, 0.58 \%$, and $0.50 \%$, respectively [40]. The lattice misfit between $\gamma$ and $\gamma^{\prime}$ phases of Co-9.2Al-9W-based superalloys was $0.53 \%$ [14], while this study measures the lattice misfit of the Co-8Ti-11V alloy which is $0.77 \%$. There is a large lattice misfit between the $\gamma$ phase and the $\gamma^{\prime}-\mathrm{Co}_{3}$ Ti phase of the alloys reinforced by $\gamma^{\prime}-\mathrm{Co}_{3} \mathrm{Ti}[41,42]$. Shinagawa et al. reported that as the Ni contents increase from $10 \%$ to $60 \%$, the lattice misfit between $\gamma$ and $\gamma^{\prime}$ phases decreases [43]. Besides, the atomic radius of $\mathrm{Ti}$ is greater than that of the $\mathrm{Al}$ and $\mathrm{W}$ elements, so the lattice constant of the $\gamma^{\prime}$ phase increases, resulting in an increase in the lattice misfit.
3.3. Microstructure and Partitioning Behavior. Figure 3 shows bright-field TEM images of the $0 \mathrm{Ni}, 5 \mathrm{Ni}$, and $10 \mathrm{Ni}$ alloys. The dual size of the $\gamma^{\prime}$ precipitates is observed in Figures 3(a)-3(d), respectively. The larger $\gamma^{\prime}$ precipitates are cubical or trigonal in shape, and the fine $\gamma^{\prime}$ precipitates are spherical particles distributed in the $\gamma$ matrix channels. They are distributed throughout the $\gamma$ matrix homogeneously. A selected area diffraction pattern (SADP) is shown in Figure 3(e), the superlattice diffraction spot of the (110) plane indicated an ordered $\mathrm{L}_{2}$ structure, and the spherical particles of the precipitates were identified as the $\mathrm{L}_{2}$-ordered $\gamma^{\prime}$ phase $\left(\mathrm{Co}_{3} \mathrm{Ti}\right.$, PDF no. 23-0938). The average sizes of fine spherical $\gamma^{\prime}$ precipitates were measured to be $18.09 \mathrm{~nm}$, $16.95 \mathrm{~nm}$, and $17.89 \mathrm{~nm}$ for the $0 \mathrm{Ni}, 5 \mathrm{Ni}$, and $10 \mathrm{Ni}$, respectively, by using the Image-Pro Plus 6.0 software. However, compared with the other two alloys, the $5 \mathrm{Ni}$ alloys possess low volume fraction of the $\gamma^{\prime}$ phase.

Figure 4 shows the XRD patterns of alloys with varied $\mathrm{Ni}$ contents. The XRD pattern of each alloy has three distinct peaks, in which crystal indices were identified as the $\left(\begin{array}{lll}1 & 1 & 1\end{array}\right)$, (2 00 ), and (2 20 ) planes, respectively. There is no other phase at the XRD patterns except for the typical two-phase microstructure $\gamma^{\prime}$ phase and $\gamma$ matrix phase.

The partitioning behaviors of the elements of the alloys with different components were analyzed by EDS equipped with TEM. Table 3 shows the partitioning situation of the elements between $\gamma$ and $\gamma^{\prime}$ in the alloy. The partitioning coefficient $K x$ is defined as $K x=C_{\gamma}{ }^{\prime-x} / C_{\gamma-x}$, where $C_{\gamma}{ }^{\prime-x}$ and $C_{\gamma-x}$ are the concentration of element X in the $\gamma^{\prime}$ phase and the $\gamma$ phase, respectively. Element $\mathrm{X}$ tends to partition into the $\gamma^{\prime}$ 


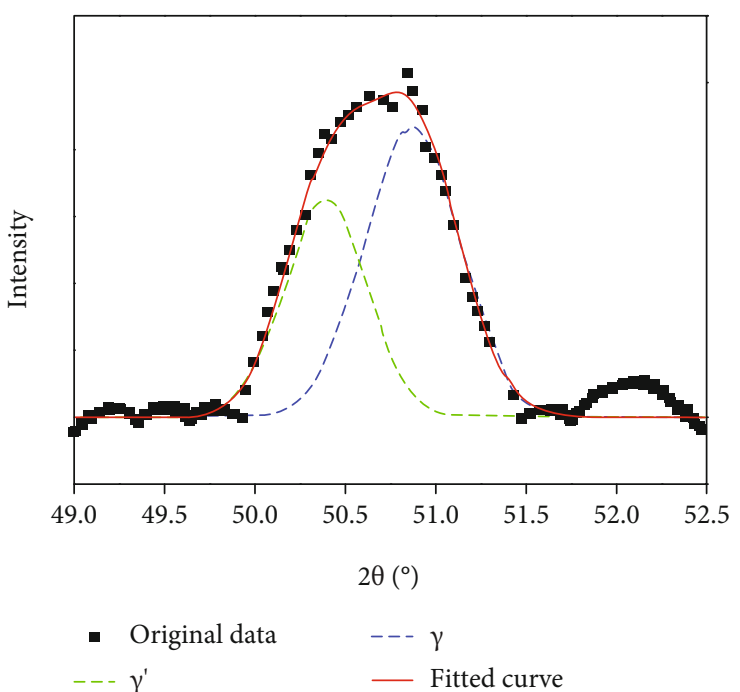

(a)

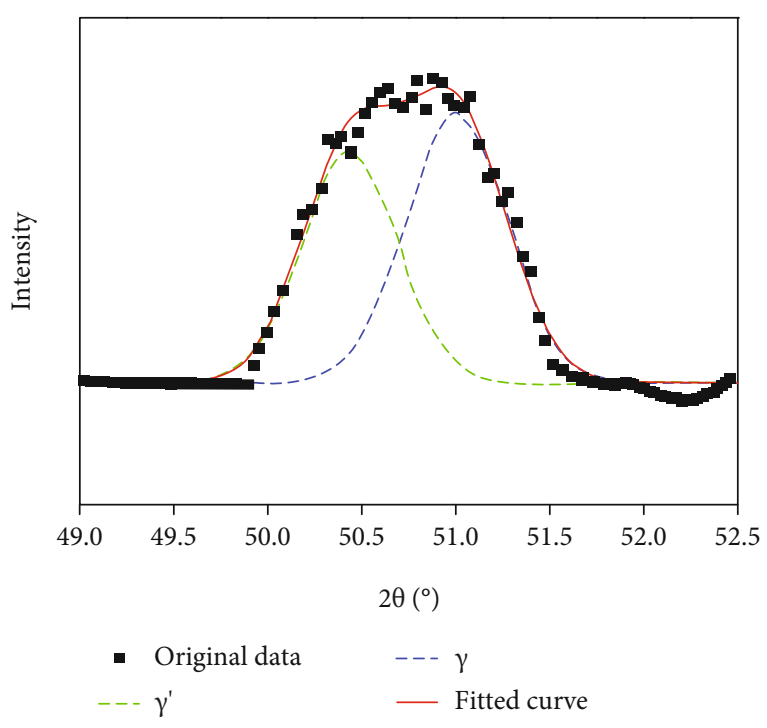

(b)

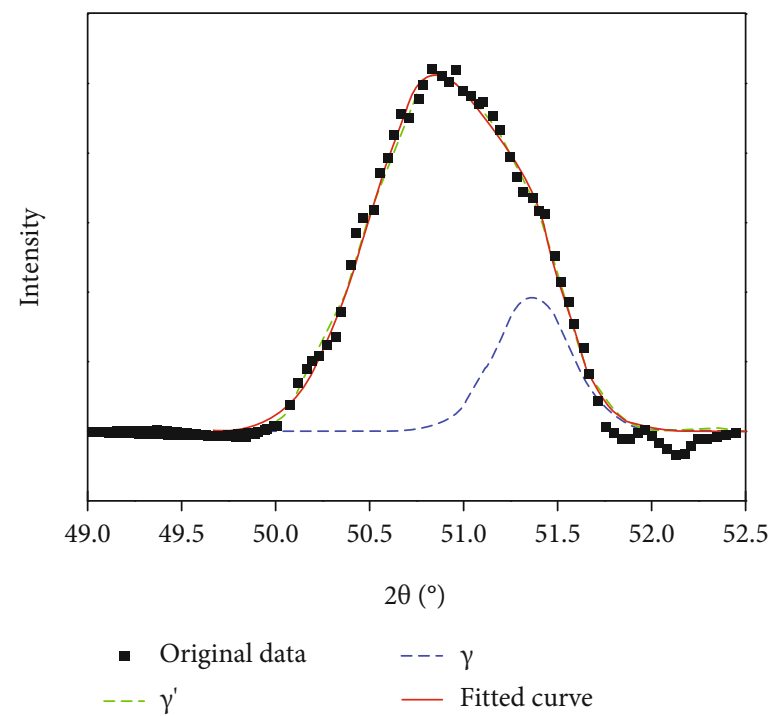

(c)

Figure 2: The X-ray diffraction (200) peaks obtained from (a) $0 \mathrm{Ni}$ alloy, (b) $5 \mathrm{Ni}$ alloy, and (c) $10 \mathrm{Ni}$ alloy aging treatment for $72 \mathrm{~h}$ at $870^{\circ} \mathrm{C}$ after solution treatment for $48 \mathrm{~h}$ at $1100^{\circ} \mathrm{C}$.

TABLE 2: Lattice constants and lattice misfit between $\gamma$ and $\gamma^{\prime}$ phases of alloys with different $\mathrm{Ni}$ contents.

\begin{tabular}{lccc}
\hline Alloys & $a_{\gamma^{\prime}}(\mathrm{nm})$ & $a_{\gamma}(\mathrm{nm})$ & $\delta(\%)$ \\
\hline Co-8Ti-11V & 0.3611 & 0.3584 & 0.74 \\
Co-8Ti-11V-5Ni & 0.3607 & 0.3583 & 0.68 \\
Co-8Ti-11V-10Ni & 0.3593 & 0.3571 & 0.61 \\
\hline
\end{tabular}

phase when $K x>1$, while element $\mathrm{X}$ tends to partition into the $\gamma$ phase when $K x<1$ [36].

It can be calculated that the partitioning coefficient of the Co element was less than 1 , so the Co element tends to partition into the $\gamma$ phase more than into the $\gamma$ phase. The partitioning coefficient of $\mathrm{Ti}, \mathrm{V}$, and $\mathrm{Ni}$ elements was greater than 1 , tending to partition into the $\gamma^{\prime}$ phase, and the Ti, V, and Ni elements were enriched in the $\gamma^{\prime}$ phase. The partitioning coefficients of each element between $\gamma$ and $\gamma^{\prime}$ phases are shown in Figure 5. From the figure, the partitioning coefficient of the $\mathrm{Co}, \mathrm{V}$, and $\mathrm{Ni}$ element was relatively stable. When the Ni contents increase to $5 \%$, the partitioning coefficients of the Ti element drop to a minimum. However, when the $\mathrm{Ni}$ contents increase to $10 \%$, the partitioning coefficients of the $\mathrm{Ti}$ element increase. The results show that the $\mathrm{Ti}$ element partitioning into the $\gamma^{\prime}$ phase was restrained for the $5 \mathrm{Ni}$ alloy and the Ti element partitioning into the $\gamma^{\prime}$ phase was promoted for the $10 \mathrm{Ni}$ alloy. The alloying elements like $\mathrm{Ti}, \mathrm{Cr}, \mathrm{Nb}, \mathrm{Mo}, \mathrm{Ta}, \mathrm{W}$, and $\mathrm{Ni}$ were usually chosen for alloying additions in Ni-based and Co-based superalloys, due to the fact that they are often added to alloys for various properties such as $\gamma^{\prime}$ phase stability and oxidation resistance [44-46]. 


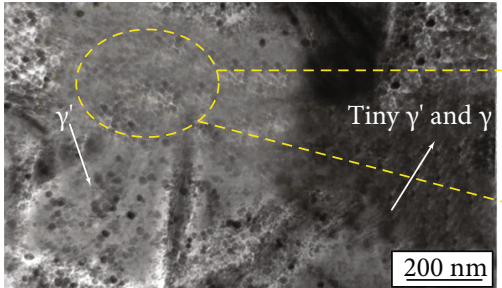

(a)

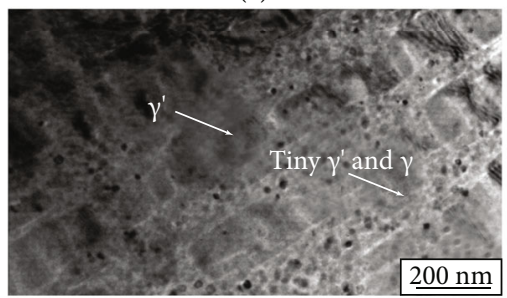

(c)

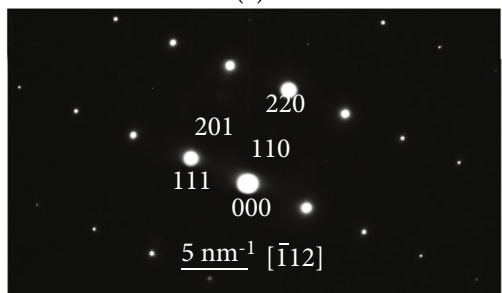

(e)

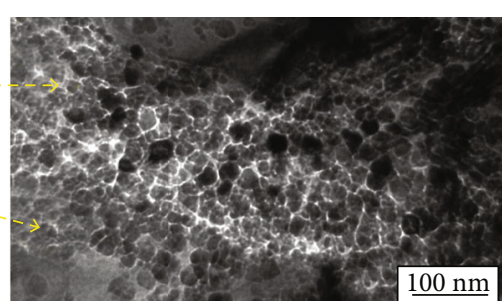

(b)

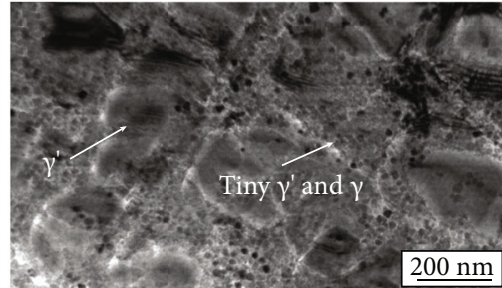

(d)

Figure 3: Bright-field TEM images of the (a, b) $0 \mathrm{Ni}$ alloy, (c) $5 \mathrm{Ni}$ alloy, and (d) $10 \mathrm{Ni}$ alloy and (e) SADP of cubical $\gamma^{\prime}$ in $5 \mathrm{Ni}$ alloy aging treatment for $72 \mathrm{~h}$ at $870^{\circ} \mathrm{C}$ after solution treatment for $48 \mathrm{~h}$ at $1100^{\circ} \mathrm{C}$.

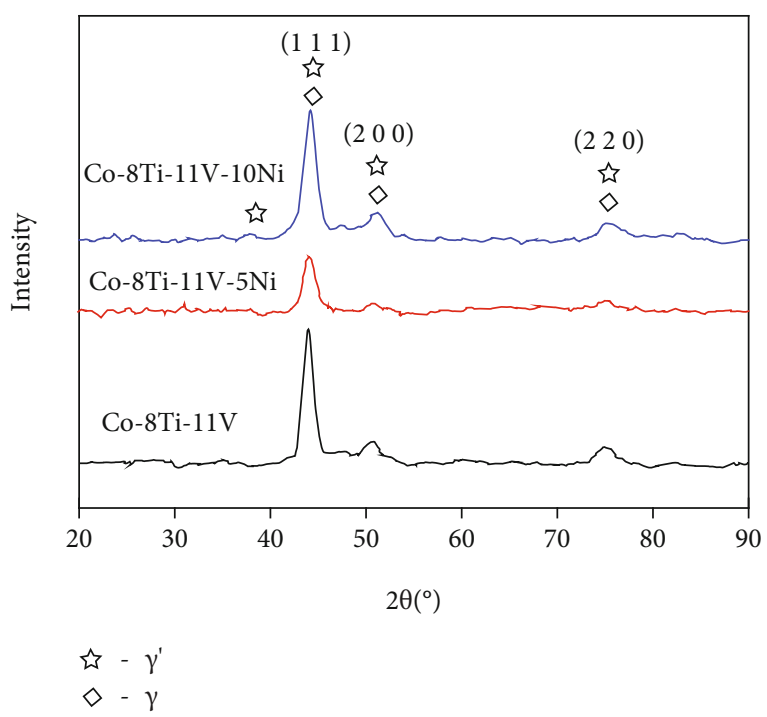

Figure 4: The XRD patterns of the $0 \mathrm{Ni}, 5 \mathrm{Ni}$, and $10 \mathrm{Ni}$ alloys.

A TEM image and elemental mappings for the $\gamma^{\prime}$ cuboidal precipitates of the $0 \mathrm{Ni}$ alloy are shown in Figure 6. As seen in Figure 6, Ti and V elements tend to be concentrated in the $\gamma^{\prime}$ phase and enriched in the $\gamma^{\prime}$ phase, whereas Co tends to partition to the $\gamma$ matrix phase and is slightly enriched in the $\gamma$ phase. Omori et al. reported that $\mathrm{Ti}, \mathrm{Nb}$, $\mathrm{Mo}, \mathrm{Ta}$, and $\mathrm{W}$ tend to partition into the $\gamma^{\prime}$ phase, while the $\mathrm{Cr}$ element tends to partition to the $\gamma$ phase, which is similar to that of Co-Al-W-based superalloys [46]. The Al element was distributed nearly uniformly in both $\gamma$ and $\gamma^{\prime}$ phases; however, the $\mathrm{V}$ element tends to partition into the $\gamma^{\prime}$ phase, which is similar to that of Co-Al-W-X superalloys [46].

3.4. The Solvus Temperature of the $\gamma^{\prime}$ Phase. Figure 7 shows the DSC heat curves of $0 \mathrm{Ni}, 5 \mathrm{Ni}$, and $10 \mathrm{Ni}$ alloys, respectively. The $T_{\text {solvus- } \gamma}$ ' means the solvus temperature of the $\gamma^{\prime}$ phase. The $T_{\text {solvus- } \gamma^{\prime}}$ of $0 \mathrm{Ni}, 5 \mathrm{Ni}$, and $10 \mathrm{Ni}$ alloys was determined to be $1167^{\circ} \mathrm{C}, 1114^{\circ} \mathrm{C}$, and $1108^{\circ} \mathrm{C}$, respectively. The result shows that $T_{\text {solvus }-\gamma}{ }^{\prime}$ of alloys decreases as the Ni content increases. The solvus temperature of the $\gamma^{\prime}$ phase in the Co-9.2Al-9W ternary system is $1263 \mathrm{~K}$ [14], and the solvus temperature of the $\gamma^{\prime}$ phase in the Co-9Al-9W alloy is $1000^{\circ} \mathrm{C}$ [5]. The $T_{\text {solvus- }}{ }^{\prime}$ of alloys $0 \mathrm{Ni}, 5 \mathrm{Ni}$, and $10 \mathrm{Ni}$ is higher that of Co-9.2Al-9W by $177^{\circ} \mathrm{C}, 124^{\circ} \mathrm{C}$, and $118^{\circ} \mathrm{C}$, respectively. The $T_{\text {solvus }-\gamma}$ ' of alloys $0 \mathrm{Ni}, 5 \mathrm{Ni}$, and $10 \mathrm{Ni}$ is higher than that of Co-9Al-9W by $167^{\circ} \mathrm{C}, 114^{\circ} \mathrm{C}$, and $108^{\circ} \mathrm{C}$, respectively. The solvus temperature of the $\gamma^{\prime}$ phase in the Co-5Ti-15V alloy is $1091^{\circ} \mathrm{C} \mathrm{[36];} \mathrm{the} \mathrm{solvus} \mathrm{tempera-}$ ture of the $\gamma^{\prime}$ phase in the Co-8Ti-11V alloy is higher that of $\mathrm{Co}-5 \mathrm{Ti}-15 \mathrm{~V}$ by $76^{\circ} \mathrm{C}$. And $\mathrm{Al}$ is found to increase the $T_{\text {solvus- }{ }^{\prime}}$ by $21^{\circ} \mathrm{C}$, but $\mathrm{Ni}$ is found to decrease the $T_{\text {solvus }-\gamma}{ }^{\prime}$ by $9^{\circ} \mathrm{C}$ [33]. The $T_{\text {solvus }-~}{ }^{\prime}$ of the Ni-based superalloy IN939 is $1100^{\circ} \mathrm{C}$ [47], while the $T_{\text {solvus- }}{ }^{\prime}$ of the Co- $8 \mathrm{Ti}-11 \mathrm{~V}$ 
TABLE 3: Equilibrium compositions of the alloy with different $\mathrm{Ni}$ contents.

\begin{tabular}{lccccc}
\hline Alloys & & $\mathrm{Co}(\%)$ & $\mathrm{Ti}(\%)$ & $\mathrm{V}(\%)$ & $\mathrm{Ni}(\%)$ \\
\hline \multirow{2}{*}{ Co-8Ti-11V } & $\gamma$ & 87.97 & 3.30 & 8.73 & - \\
& $\gamma^{\prime}$ & 78.95 & 8.11 & 12.95 & - \\
Co-8Ti-11V-5Ni & $\gamma$ & 82.72 & 2.82 & 10.17 & 4.29 \\
& $\gamma^{\prime}$ & 75.36 & 6.23 & 13.48 & 4.93 \\
Co-8Ti-11V-10Ni & $\gamma$ & 77.22 & 2.49 & 9.87 & 10.42 \\
& $\gamma^{\prime}$ & 68.31 & 6.47 & 13.56 & 11.66 \\
\hline
\end{tabular}

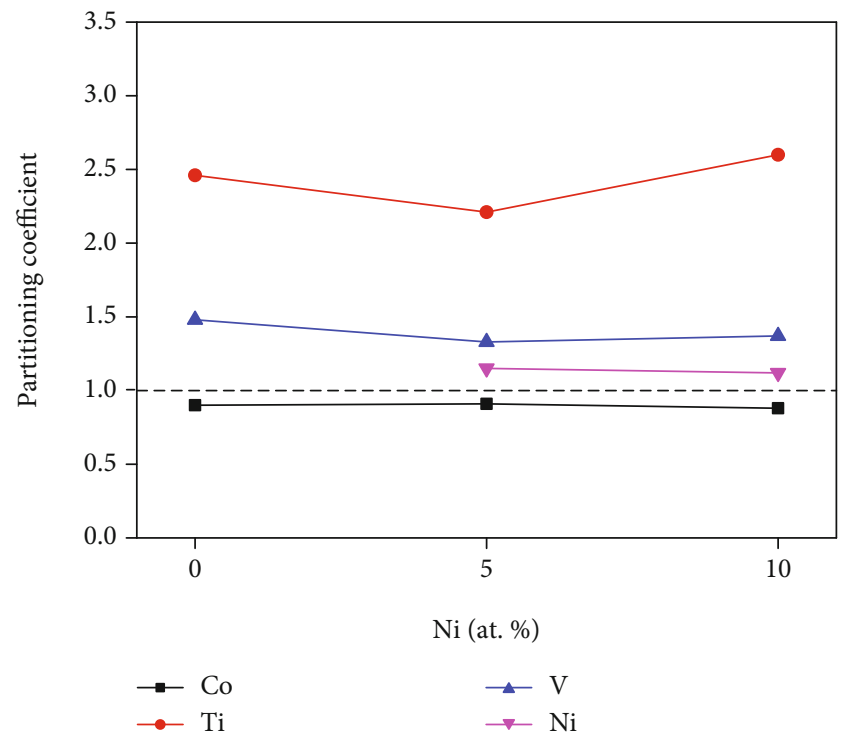

Figure 5: Partitioning coefficients of each element between $\gamma$ and $\gamma^{\prime}$ phases.

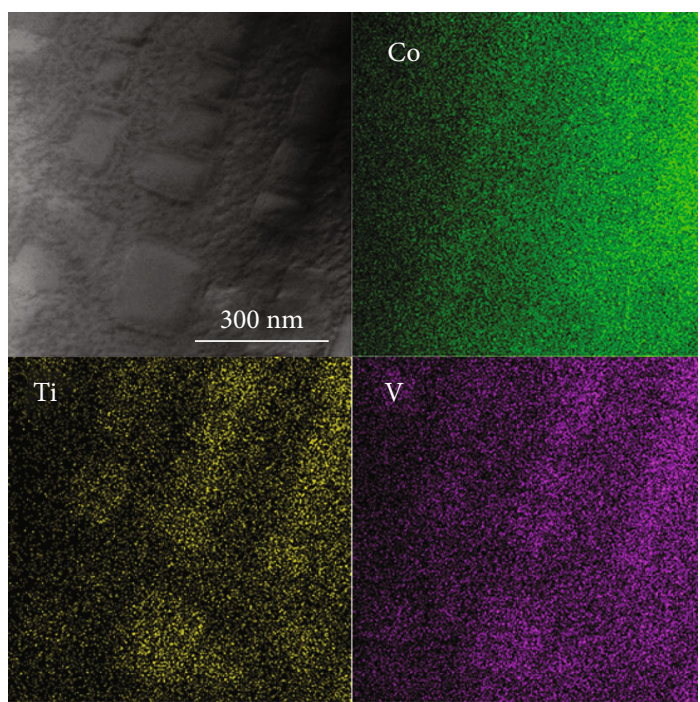

FIGURE 6: STEM image and elemental mappings for the $\gamma^{\prime}$ cuboidal precipitates of the $0 \mathrm{Ni}$ alloy.

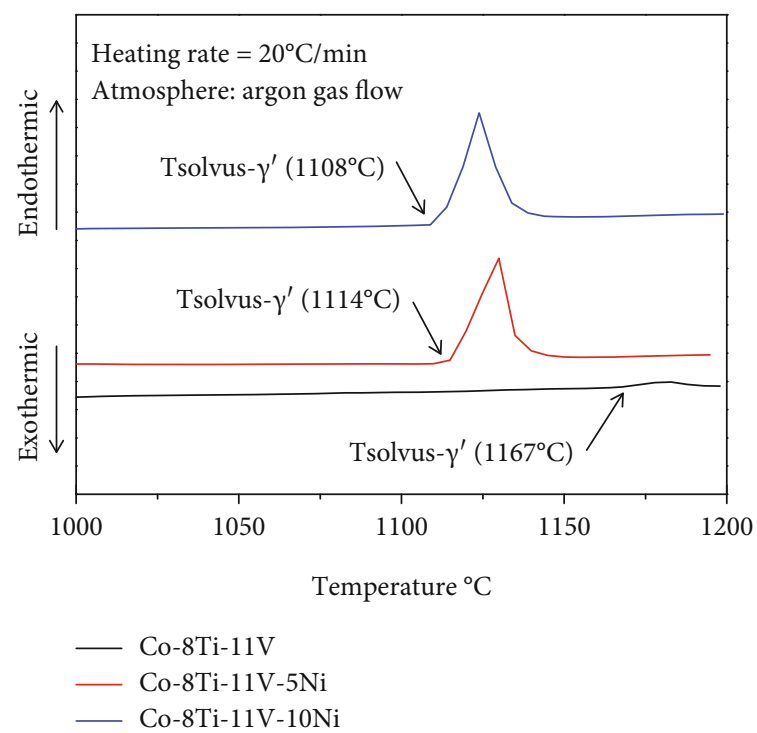

FIgure 7: DSC heat curves of $0 \mathrm{Ni}, 5 \mathrm{Ni}$, and $10 \mathrm{Ni}$ alloys.

alloy is higher than that of the Ni-based superalloy IN-939 by $67^{\circ} \mathrm{C}$.

3.5. Mechanical Properties. Figure 8 shows the hightemperature compression curves and histogram of $0 \mathrm{Ni}$, $5 \mathrm{Ni}$, and $10 \mathrm{Ni}$ alloys after high-temperature compression tests at $1000^{\circ} \mathrm{C}$. As can be seen in Figure 8 , the yield strength and ultimate strength of the $10 \mathrm{Ni}$ alloy were at the maximum, at $219 \mathrm{MPa}$ and $240 \mathrm{MPa}$, respectively. The yield strength and ultimate strength of the $0 \mathrm{Ni}$ alloy were $176 \mathrm{MPa}$ and $235 \mathrm{MPa}$, respectively, which were similar to those of the Co-5Ti-15V alloy [36]. Compared with the other two alloys, the yield strength and ultimate strength of the $5 \mathrm{Ni}$ alloy were the smallest, which were only $105 \mathrm{MPa}$ and $131 \mathrm{MPa}$, respectively. In general, there is a close relationship with the lattice misfit, the volume, and the size of the $\gamma^{\prime}$ phase, the partitioning behavior of the elements in the alloy, and the high-temperature mechanical properties of the alloy $[48,49]$. Adding $\gamma^{\prime}$ phase stabilization elements to the alloy would increase the volume fraction of the $\gamma^{\prime}$ phase [36], which improves the high-temperature mechanical properties of the alloy. In this study, the $\mathrm{Ni}$ element exhibits a slight tendency to partition into the $\gamma^{\prime}$ phase and is enriched in the $\gamma^{\prime}$ phase, so the mechanical properties of the $10 \mathrm{Ni}$ alloy were better than those of the other two alloys.

3.6. Compression Deformation. There is a key relationship between dislocation deformation and mechanical properties of alloys. Figure 9 shows the bright-field TEM and SEM images of the alloy with varied $\mathrm{Ni}$ contents after hightemperature compression tests. There are a considerable number of dislocations in the $\gamma^{\prime}$ phase of the $0 \mathrm{Ni}$ alloy. The $\gamma^{\prime}$ phase is sheared by the dislocations, as shown in Figure 9(a). Figure 9(b) shows that the morphology of the $\gamma$ ' phase in the alloy has been changed, which indicated that the large cubical $\gamma^{\prime}$ has been repeatedly cut by dislocations. 


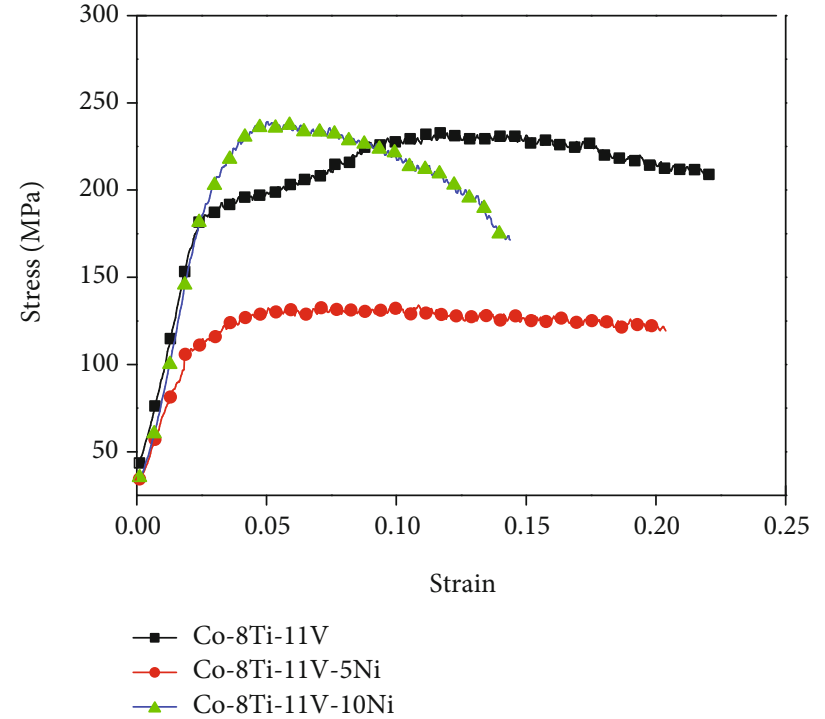

(a)

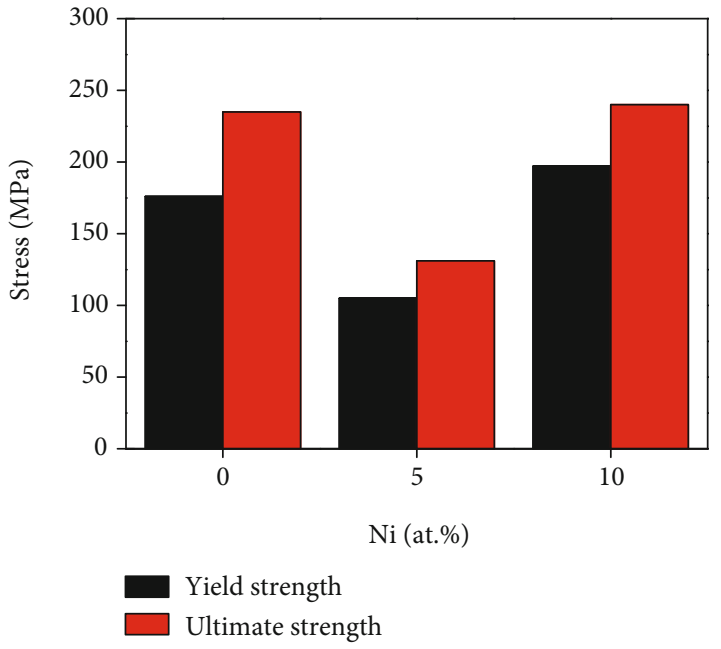

(b)

FIgURE 8: High-temperature compression curves and histogram of $0 \mathrm{Ni}, 5 \mathrm{Ni}$, and $10 \mathrm{Ni}$ alloys of high-temperature compression tests at $1000^{\circ} \mathrm{C}$.

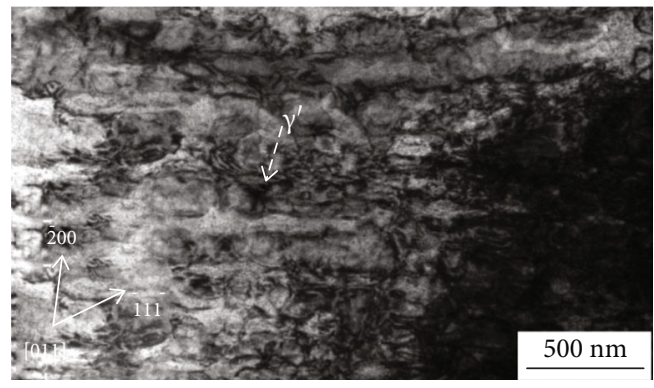

(a)

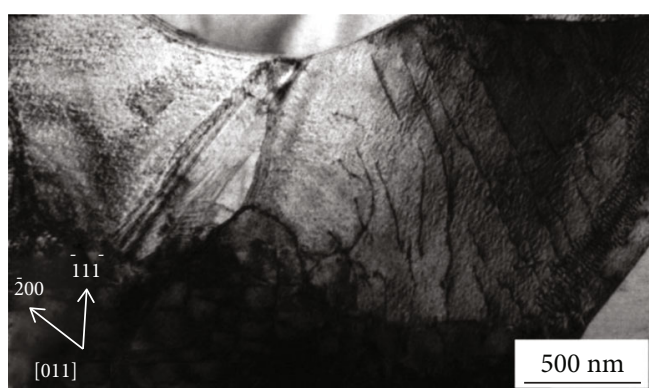

(c)

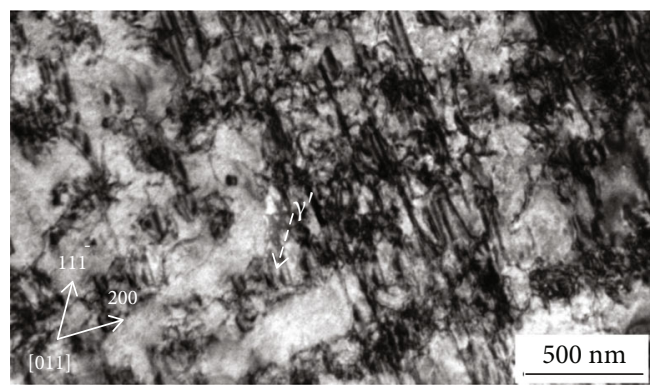

(e)

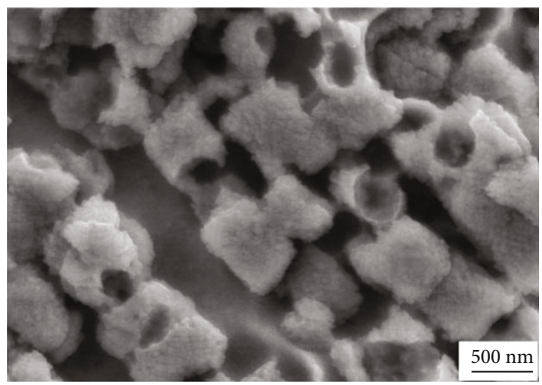

(b)

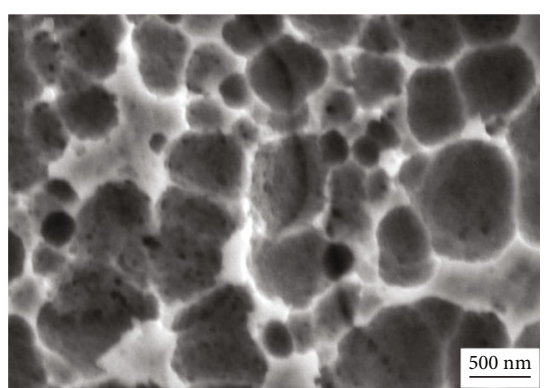

(d)

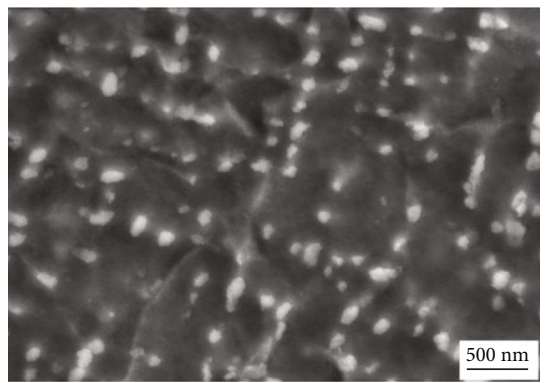

(f)

FIGURE 9: Bright-field TEM and SEM images of the (a, b) 0Ni alloy, (c, d) $5 \mathrm{Ni}$ alloy, and $(\mathrm{e}, \mathrm{f}) 10 \mathrm{Ni}$ alloy after high-temperature compression tests at $1000^{\circ} \mathrm{C}$. 
Thereby, there seem many fine particles on the surface of large $\gamma^{\prime}$. These morphologies were the results of dislocation cutting the large $\gamma^{\prime}$. So the $\gamma^{\prime}$ phase has a certain strengthening role in the alloy. In Figure 9(c), the dislocation glide in the $\gamma$ phase in the $5 \mathrm{Ni}$ alloy and the morphologies of the $\gamma^{\prime}$ phase could not be seen under the effect of temperature and stress, as shown in Figure 9(d). In this manner, the $\gamma^{\prime}$ phase cannot play a remarkable strengthening role. Therefore, the hightemperature compression performance of the $5 \mathrm{Ni}$ alloy is poor. Figure 9(e) shows that not only do a large number of dislocations exist in the $\gamma^{\prime}$ phase of the $10 \mathrm{Ni}$ alloy but also some stacking faults appear in the $\gamma$ phase matrix channels. But the shape of the $\gamma^{\prime}$ phase changed, and the size is rather small compared to that in the $0 \mathrm{Ni}$ alloy. The volume faction of the $\gamma^{\prime}$ phase dropped remarkably compared to the alloy prior to the compression test, as shown in Figure 9(f). For the Co-30Ni alloy that has a high content of Ni, the dislocations easily shear the $\gamma^{\prime}$ precipitates [50]. The massive dislocation tangles around the $\gamma^{\prime}$ precipitates indicating that the $\gamma^{\prime}$ is effective in retarding dislocation movement. The surface of retained $\gamma^{\prime}$ is smooth, indicating that the $\gamma^{\prime}$ particle is hard to be cut by dislocation. And although the $\gamma^{\prime}$ phase of the alloy becomes significantly smaller and the volume fraction dropped, the $\gamma^{\prime}$ phase in the $10 \mathrm{Ni}$ alloy still can play a key strengthening role. The strengthening effect of $\gamma^{\prime}$ in the $10 \mathrm{Ni}$ alloy is better than that in the $0 \mathrm{Ni}$ alloy which may result from the higher Ti concentration induced by more $\mathrm{Ni}$ alloying, which is illustrated in Figure 5.

\section{Conclusions}

In conclusion, the effects of $\mathrm{Ni}$ on microstructure, elemental partition behavior, phase transition temperature, lattice misfit between $\gamma$ and $\gamma^{\prime}$ phases, and mechanical properties of the $0 \mathrm{Ni}, 5 \mathrm{Ni}$, and $10 \mathrm{Ni}$ alloys were investigated. The lattice misfit between $\gamma$ and $\gamma^{\prime}$ phases of the alloys decreases from $0.74 \%$ to $0.61 \%$ as the Ni contents increase from 0 to $10 \%$. There is a dual-size $\gamma^{\prime}$ precipitate phase in the alloys. The larger precipitate was cuboidal in shape, and the average sizes of the $\gamma^{\prime}$ phase were measured to be $312.10 \mathrm{~nm}, 112.86 \mathrm{~nm}$, and $141.84 \mathrm{~nm}$ for the $0 \mathrm{Ni}, 5 \mathrm{Ni}$, and $10 \mathrm{Ni}$, respectively. The smaller $\gamma^{\prime}$ precipitates were spherical particles with an average size of $18.09 \mathrm{~nm}, 16.95 \mathrm{~nm}$, and $17.89 \mathrm{~nm}$ for the $0 \mathrm{Ni}$, $5 \mathrm{Ni}$, and $10 \mathrm{Ni}$, respectively. $\mathrm{Ti}, \mathrm{V}$, and $\mathrm{Ni}$ exhibit a slight tendency to partition into the $\gamma^{\prime}$ phase, while Co shows a slight tendency to partition into the $\gamma$ phase. The solvus temperatures of the $\gamma^{\prime}$ phase were measured to be $1167^{\circ} \mathrm{C}, 1114^{\circ} \mathrm{C}$, and $1108^{\circ} \mathrm{C}$ for the $0 \mathrm{Ni}, 5 \mathrm{Ni}$, and $10 \mathrm{Ni}$ alloys, respectively, by using differential scanning calorimetry (DSC), and the solvus temperature of the $\gamma^{\prime}$ phase decreases as the $\mathrm{Ni}$ content increases. The yield strength of the $0 \mathrm{Ni}, 5 \mathrm{Ni}$, and $10 \mathrm{Ni}$ alloys is about $176 \mathrm{MPa}, 105 \mathrm{MPa}$, and $219 \mathrm{MPa}$, respectively. And ultimate strength of the $0 \mathrm{Ni}, 5 \mathrm{Ni}$, and $10 \mathrm{Ni}$ alloys is about $235 \mathrm{MPa}, 131 \mathrm{MPa}$, and $240 \mathrm{MPa}$, respectively. The yield strength and the ultimate strength of the $10 \mathrm{Ni}$ alloy are the highest. The $\gamma^{\prime}$ phase can play a certain strengthening role in the $0 \mathrm{Ni}$ and the $10 \mathrm{Ni}$ alloy; thus, the high-temperature compressive strength of the $0 \mathrm{Ni}$ and $10 \mathrm{Ni}$ alloys is relatively high. However, the $\gamma^{\prime}$ phase of the $5 \mathrm{Ni}$ alloy is no longer visible; thereby, it cannot play a good strengthening role; consequently, its strength is the lowest.

\section{Data Availability}

The PDF data used to support the findings of this study have been deposited in PDF 2002 card no. 23-0938.

\section{Conflicts of Interest}

The authors declare that they have no conflicts of interest.

\section{Acknowledgments}

This research was financially supported by the project (51471079) from the National Natural Science Foundation of China and the project (BK20130464) from the Jiangsu Natural Science Foundation. Pengjie Zhou also would like to acknowledge the financial support from the Jiangsu Government Scholarship for Oversea Studies. This work was also supported by the State Key Laboratory of Powder Metallurgy, Central South University, Changsha, China; Key Research and Development Program of Shaanxi (program nos. 2019GY-151, 2019GY-178, and 2020GY-251); National Natural Science Foundation of China (51901193); and Science and Technology Plan Project of Weiyang District in Xi'an City (201905).

\section{References}

[1] T. Nishizawa and K. Ishida, "The Co-Ni (cobalt-nickel) system," Bulletin of Alloy Phase Diagrams, vol. 4, pp. 390395, 1983.

[2] L. Swartzendruber, V. Itkin, and C. Alcock, "The Fe-Ni (ironnickel) system," Journal of Phase Equilibria, vol. 12, no. 3, pp. 288-312, 1991.

[3] W. Huang and Y. A. Chang, "A thermodynamic analysis of the Ni-Al system," Intermetallics, vol. 6, pp. 487-498, 1991.

[4] T. M. Pollock, "Alloy design for aircraft engines," Natural Materials, vol. 15, no. 8, pp. 809-815, 2016.

[5] A. Suzuki, G. C. DeNolf, and T. M. Pollock, "Flow stress anomalies in $\gamma / \gamma^{\prime}$ two-phase Co-Al-W-base alloys," Scripta Materialia, vol. 56, no. 5, pp. 385-388, 2007.

[6] T. M. Pollock, J. Dibbern, M. Tsunekane, J. Zhu, and A. Suzuki, "New Co-based $\gamma-\gamma^{\prime}$ high-temperature alloys," JOM, vol. 62, pp. 58-63, 2010.

[7] E. A. Lass, M. E. Williams, C. E. Campbell, K. M. Moon, and U. R. Kattner, " $\gamma$ ' phase stability and phase equilibrium in ternary Co-Al-W at $900^{\circ} \mathrm{C}$," Journal of Phase Equilibria and Diffusion, vol. 35, no. 6, pp. 711-723, 2014.

[8] E. A. Lass, R. D. Grist, and M. E. Williams, "Phase equilibria and microstructural evolution in ternary Co-Al-W between 750 and $1100^{\circ} \mathrm{C}$," Journal of Phase Equilibria and Diffusion, vol. 37, no. 4, pp. 387-401, 2016.

[9] H. Y. Yan, V. A. Vorontsov, and D. Dye, "Alloying effects in polycrystalline $\gamma^{\prime}$ strengthened Co-Al-W base alloys," Intermetallics, vol. 48, pp. 44-53, 2014. 
[10] H. Chinen, J. Sato, T. Omori et al., "New ternary compound $\mathrm{Co}_{3}(\mathrm{Ge}, \mathrm{W})$ with $\mathrm{Ll}_{2}$ structure," Scripta Materialia, vol. 56, no. 2, pp. 141-143, 2007.

[11] M. S. Atas and M. Yildirim, "Morphological development, coarsening, and oxidation behavior of $\mathrm{Ni}-\mathrm{Al}-\mathrm{Nb}$ superalloys," Journal of Materials Engineering and Performance, vol. 29, no. 7, pp. 4421-4434, 2020.

[12] Y. Plotnikov Elizaveta, Z. Mao, B. Sung-Il et al., "A correlative four-dimensional study of phase-separation at the subnanoscale to nanoscale of a Ni Al alloy," Acta Materialia, vol. 171, pp. 306-333, 2019.

[13] M. S. Atas and M. Yildirim, "Temporal evolution, coarsening behavior and oxidation resistance of $\mathrm{Ni}-15 \mathrm{Al}$ superalloy," Journal of Alloys and Compounds, vol. 809, article 151784, 2019.

[14] J. Sato, T. Omori, K. Oikawa, I. Ohnuma, R. Kainuma, and K. Ishida, "Cobalt-base high-temperature alloys," Science, vol. 312, no. 5770, pp. 90-91, 2006.

[15] S. Kobayashi, Y. Tsukamoto, T. Takasugi et al., "Determination of phase equilibria in the Co-rich Co-Al-W ternary system with a diffusion-couple technique," Intermetallics, vol. 17, no. 12, pp. 1085-1089, 2009.

[16] K. Shinagawa, T. Omori, J. Sato et al., "Phase equilibria and microstructure on $\gamma^{\prime}$ phase in Co-Ni-Al-W system," Materials Transactions, vol. 49, no. 6, pp. 1474-1479, 2008.

[17] I. Povstugar, P. P. Choi, S. Neumeier et al., "Elemental partitioning and mechanical properties of $\mathrm{Ti}$ - and $\mathrm{Ta}$-containing Co-Al-W-base superalloys studied by atom probe tomography and nanoindentation," Acta Materialia, vol. 78, pp. 78-85, 2014.

[18] K. Shinagawa, H. Chinen, T. Omori, K. Oikawa, I. Ohnuma, and R. Kainuma, "Phase equilibria and thermodynamic calculation of the Co-Ta binary system," Intermetallics, vol. 49, pp. 87-97, 2014.

[19] M. Ooshima, K. Tanaka, N. L. Okamoto, K. Kishida, and H. Inui, "Effects of quaternary alloying elements on the $\gamma^{\prime}$ solvus temperature of $\mathrm{Co}-\mathrm{Al}-\mathrm{W}$ based alloys with $\mathrm{fcc} / \mathrm{L}_{2}$ twophase microstructures," Journal of Alloys and Compounds, vol. 508, no. 1, pp. 71-78, 2010.

[20] P. J. Bocchini, C. K. Sudbrack, R. D. Noebe, D. C. Dunand, and D. N. Seidman, "Microstructural and creep properties of boron- and zirconium-containing cobalt-based superalloys," Materials Science and Engineering A, vol. 682, pp. 260-269, 2017.

[21] P. J. Bocchini, E. A. Lass, K. W. Moon et al., "Atom-probe tomographic study of $\gamma / \gamma^{\prime}$ interfaces and compositions in an aged Co-Al-W superalloy," Scripta Materialia, vol. 68, no. 8, pp. 563-566, 2013.

[22] P. J. Bocchini, C. K. Sudbrack, D. J. Sauza, R. D. Noebe, D. N. Seidman, and D. C. Dunand, "Effect of tungsten concentration on microstructures of Co-10Ni-6Al- $(0,2,4,6) \mathrm{W}-6 \mathrm{Ti}$ (at\%) cobalt-based superalloys," Materials Science and Engineering A, vol. 700, pp. 481-486, 2017.

[23] D. J. Sauza, P. J. Bocchini, D. C. Dunand, and D. N. Seidman, "Influence of ruthenium on microstructural evolution in a model Co-Al-W superalloy," Acta Materialia, vol. 117, pp. 135-145, 2016.

[24] V. A. Vorontsov, J. S. Barnard, K. M. Rahman, H. Y. Yan, P. A. Midgley, and D. Dye, "Coarsening behaviour and interfacial structure of $\gamma^{\prime}$ precipitates in Co-Al-W based superalloys," Acta Materialia, vol. 120, pp. 14-23, 2016.
[25] S. K. Makineni, B. Nithin, and K. Chattopadhyay, "A new tungsten-free $\gamma-\gamma^{\prime}$ Co-Al-Mo-Nb-based superalloy," Scripta Materialia, vol. 98, pp. 36-39, 2015.

[26] S. K. Makineni, B. Nithin, D. Palanisamy, and K. Chattopadhyay, "Phase evolution and crystallography of precipitates during decomposition of new "tungsten-free" $\mathrm{Co}(\mathrm{Ni})-\mathrm{Mo}-\mathrm{Al}-\mathrm{Nb} \quad \gamma-\gamma^{\prime}$ superalloys at elevated temperatures," Journal of Materials Science, vol. 51, no. 17, pp. 7843 7860, 2016.

[27] S. K. Makineni, A. Samanta, T. Rojhirunsakool et al., "A new class of high strength high temperature cobalt based $\gamma-\gamma^{\prime}$ Co-Mo-Al alloys stabilized with Ta addition," Acta Materialia, vol. 97, pp. 29-40, 2015.

[28] S. K. Makineni, B. Nithin, and K. Chattopadhyay, "Synthesis of a new tungsten-free $\gamma-\gamma^{\prime}$ cobalt-based superalloy by tuning alloying additions," Acta Materialia, vol. 85, pp. 85-94, 2015.

[29] Y. Aoki and J. Echigoya, "Phase separation in an 18.2 at\% VCo alloy annealed at $1073 \mathrm{~K}$," Scripta Metallurgica, vol. 19, no. 5, pp. 639-642, 1985.

[30] P. Viatour, J. M. Drapier, and D. Coutsouradis, "Stability of the gamma prime $\mathrm{Co}_{3} \mathrm{Ti}$ compound in simple and complex $\mathrm{Co}$ alloys," Cobalt, vol. 3, pp. 67-74, 1973.

[31] G. J. Zhou, J. G. Tang, Y. Zhou, W. K. An, and A. H. Cai, "Phase equilibria in the Co-Ti-V system at $873 \mathrm{~K}$," Journal of Alloys and Compounds, vol. 602, pp. 49-52, 2014.

[32] F. L. R. Tirado, J. P. Toinin, and D. C. Dunand, " $\gamma+\gamma^{\prime}$ microstructures in the Co-Ta-V and Co-Nb-V ternary systems," Acta Materialia, vol. 151, pp. 137-148, 2018.

[33] A. V. Davydov, U. R. Kattner, D. Jossel et al., "Determination of the Co-Ti congruent melting point and thermodynamic reassessment of the Co-Ti system," Metallurgical and Materials Transactions A: Physical Metallurgy and Materials Science, vol. 32, no. 9, pp. 2175-2186, 2001.

[34] C. H. Zenk, I. Povstugar, R. Li et al., "A novel type of Co-Ti-Crbase $\gamma / \gamma^{\prime}$ superalloys with low mass density," Acta Materialia, vol. 135, pp. 244-251, 2017.

[35] J. J. Ruan, C. P. Wang, C. C. Zhao, S. Y. Yang, T. Yang, and X. J. Liu, "Experimental investigation of phase equilibria and microstructure in the Co-Ti-V ternary system," Intermetallics, vol. 49, pp. 121-131, 2014.

[36] J. J. Ruan, X. J. Liu, S. Y. Yang et al., "Novel Co-Ti-V-base superalloys reinforced by $\mathrm{L}_{2}$-ordered $\gamma^{\prime}$ phase," Intermentallics, vol. 92, pp. 126-132, 2018.

[37] S. Meher, S. Nag, J. Tiley, A. Goel, and R. Banerjee, "Coarsening kinetics of $\gamma^{\prime}$ precipitates in cobalt-base alloys," Acta Materialia, vol. 61, no. 11, pp. 4266-4276, 2013.

[38] P. Pandey, A. K. Sawant, B. Nithin et al., "On the effect of Re addition on microstructural evolution of a CoNi-based superalloy," Acta Materialia, vol. 168, pp. 37-51, 2019.

[39] W. Z. Wang, T. Jin, J. L. Liu, X. F. Sun, H. R. Guan, and Z. Q. $\mathrm{Hu}$, "Role of Re and Co on microstructures and $\gamma^{\prime}$ coarsening in single crystal superalloys," Materials Science and Engineering A, vol. 479, no. 1-2, pp. 148-156, 2008.

[40] L. L. Li, C. P. Wang, Y. C. Chen et al., "Effect of Re on microstructure and mechanical properties of $\gamma / \gamma^{\prime}$ Co-Ti-based superalloys," Intermetallics, vol. 115, p. 106612, 2019.

[41] T. Takasugi and O. Izumi, "High temperature strength and ductility of polycrystalline $\mathrm{Co}_{3}$ Ti," Acta Metallurgica, vol. 33, no. 1, pp. 39-48, 1985.

[42] T. Takasugi and O. Izumi, "Recrystallization and grain growth of $\mathrm{Co}_{3} \mathrm{Ti}$," Acta Metallurgica, vol. 33, no. 1, pp. 49-58, 1985. 
[43] K. Shinagawa, T. Omori, K. Oikawa, R. Kainuma, and K. Ishida, "Ductility enhancement by boron addition in CoAl-W high-temperature alloys," Scripta Materialia, vol. 61, no. 6, pp. 612-615, 2009.

[44] P. J. Bocchini, C. K. Sudbrack, R. D. Noebe, D. C. Dunand, and D. N. Seidman, "Effects of titanium substitutions for aluminum and tungsten in Co-10Ni-9Al-9W (at\%) superalloys," Materials Science and Engineering, vol. 705, pp. 122-132, 2017.

[45] B. Nithin, A. Samanta, S. K. Makineni et al., "Effect of Cr addition on $\gamma-\gamma^{\prime}$ cobalt-based Co-Mo-Al-Ta class of superalloys: a combined experimental and computational study," Journal of Materials Science, vol. 52, no. 18, pp. 11036-11047, 2017.

[46] T. Omori, K. Oikawa, J. Sato et al., "Partition behavior of alloying elements and phase transformation temperatures in CoAl-W-base quaternary systems," Intermetallics, vol. 32, pp. 274-283, 2013.

[47] M. R. Jahangiri, S. M. A. Boutorabi, and H. Arabi, "Study on incipient melting in cast Ni base IN939 superalloy during solution annealing and its effect on hot workability," Materials Science and Technology, vol. 28, no. 12, pp. 1402-1413, 2012.

[48] J. X. Zhang, H. Harada, Y. Koizumi, and T. Kobayashi, "Dislocation motion in the early stages of high-temperature lowstress creep in a single-crystal superalloy with a small lattice misfit," Journal of Materials Science, vol. 45, no. 2, pp. 523$532,2010$.

[49] J. Y. Chen, B. Zhao, Q. Feng, L. M. Cao, and Z. Q. Sun, "Effects of $\mathrm{Ru}$ and $\mathrm{Cr}$ on $\gamma / \gamma^{\prime}$ microstructural evolution of Ni-based single crystal superalloys during heat treatment," Acta Metallurgica Sinica, vol. 46, no. 8, pp. 897-906, 2010.

[50] S. S. Qu, Y. J. Li, M. L. He et al., "Microstructural evolution and compression property of a novel $\gamma^{\prime}$-strengthened directionally solidified CoNi-base superalloy," Materials Science and Engineering $A$, vol. 761, article 138034, 2019. 